\title{
Prevalence and Incidence of HIV Infection among Fishermen along Lake Victoria Beaches in Kisumu County, Kenya
}

\author{
Raphael Omusebe Ondondo ${ }^{1,2,3,4^{*}}$, Zipporah Waithera Ng'ang'a², Solomon Mpoke1, \\ Michael Kiptoo, ${ }^{1,2}$, Elizabeth A. Bukusi 1,2,4 \\ ${ }^{1}$ Kenya Medical Research Institute (KEMRI), Nairobi, Kenya \\ 2Jomo Kenyatta University of Agriculture and Technology, Nairobi, Kenya \\ ${ }^{3}$ Masinde Muliro University of Science and Technology, Kakamega, Kenya \\ ${ }^{4} \mathrm{KEMRI}$ in Collaboration with University of California San Francisco, San Francisco, USA \\ Email: raphondondo@gmail.com
}

Received 5 April 2014; revised 5 May 2014; accepted 30 May 2014

Copyright (C) 2014 by authors and Scientific Research Publishing Inc.

This work is licensed under the Creative Commons Attribution International License (CC BY). http://creativecommons.org/licenses/by/4.0/

(c) (i) Open Access

\section{Abstract}

Background: Herpes simplex virus type-2 (HSV-2) and human papillomavirus (HPV) are common sexually transmitted infections (STIs) among fishing communities and are associated with high HIV prevalence in this underserved population. However, there is limited knowledge on HIV incidence among fishermen. This study aimed at determining prevalence, incidence and risk factors associated with HIV infection among fishermen in Kisumu Kenya. Methods: Three hundred fishermen were evaluated for baseline HIV, HSV-2, HPV infection and a structured questionnaire administered. HIV incidence was assessed after 12 months among those initially HIV negative. HIV incidence rate in person-years and prevalence were estimated. Multivariate logistic regression was used to determine factors independently associated with HIV acquisition. Results: HIV prevalence was $23.3 \%$ (95\% CI: 18.5 - 28.1). Risk factors for baseline HIV prevalence were older age (aOR = 2.13; 95\% CI: 1.25 - 5.07), history of STI (aOR 4.21; 95\% CI: 2.07 - 9.34), baseline HPV infection (aOR 2.13; 95\% CI: 1.05 - 4.77), number of lifetime sexual partners ( $>5$ ) aOR = 5.76 (95\% CI: 1.41 - 13.57) and transactional sex (aOR $=10.98$; 95\% CI: 1.86 - 19.34). Condom uses with new sexual partner (aOR $0.21,95 \% \mathrm{CI}$ : 0.08 - 0.55) and during most recent sexual act (aOR 0.09, 95\% CI: 0.03 - 0.61), were negatively associated with HIV prevalence. HIV incidence was $4.2(95 \% \mathrm{CI}=1.3$ 7.1) per 100 person-years with being single (aIRR $=8.32$; 95\% CI: $1.27-54.67$ ) as an independent risk factor. Condom use with new sexual partner (aIRR $=0.11 ; 95 \% \mathrm{CI}: 0.01-0.89$ ) and recent sex with wife/regular girlfriend (compared to sex worker/casual partner; aIRR $=0.03 ; 95 \% \mathrm{CI}$ : 0.01 0.35) were associated with reduced risk of HIV acquisition. Conclusion: Inconsistent condom use and transactional/casual sexual partnerships were the main high-risk sexual behaviors in addi-

\footnotetext{
${ }^{*}$ Corresponding author.
}

How to cite this paper: Ondondo, R.O., Ng'ang'a, Z.W., Mpoke, S., Kiptoo, M. and Bukusi, E.A. (2014) Prevalence and Incidence of HIV Infection among Fishermen along Lake Victoria Beaches in Kisumu County, Kenya. World Journal of AIDS, 4, 219-231. http://dx.doi.org/10.4236/wja.2014.42027 
tion to marital status explaining the high HIV acquisition rate among fishermen. Intensified safer sex promotion is urgently needed in this subpopulation to avert new HIV infections.

\author{
Keywords \\ HIV, Incidence, Prevalence, Fishermen, Sexual Behavior
}

\title{
1. Introduction
}

The HIV-AIDS pandemic is currently in its fourth decade of existence since the first case was reported in 1981 [1]. However, the global distribution of the virus in the population is highly varied geographically, by age, gender, race, and occupation [1]-[3]. Socio-economic, behavioral characteristics and cultural practices are also thought to contribute to the spread of HIV [1] [4]. Generally, HIV prevalence is highest in countries located in Sub-Sahara Africa [1]. In the US and Europe, high HIV rates are observed among injection drug users (IDUs) and young men who have sex with men (MSM), particularly among young African American MSM [1] [5]. In Sub Saharan Africa, heterosexual transmission accounts for the majority of HIV infection [6]-[8]. Disparities in the distribution of HIV across different populations (subpopulations) suggest existence of variable risk factors predisposing individuals within these populations with varying levels of risk for HIV infection. Similarly, sex workers and long distance truck drivers have been reported to have higher prevalence of HIV when compared to the general population [9]-[11]. This observation may largely be due to modified sexual practices or/and rapidly expanding sexual networks associated with these occupations.

HIV prevalence ( $20 \%$ to $28 \%$ ) among fishing communities is higher compared to the general population [12]-[16]. This has posed a serious threat to the fishing industry [13] [17]. Notably, access to care from public health facilities remains a challenge for this underserved population [18]. The fishing industry therefore presents an occupational risk for HIV infection, explained partially by the migratory nature of the fishing and fish trade activities [19]. Several studies and national survey in Kenya have documented high prevalence of HIV infection among the fishing communities including among fishermen [15] [16] [19]. However, HIV incidence and associated risk factors among this population remain largely unavailable. Quantification of HIV acquisition rates and exploring risk factors related to HIV incidence are crucial steps in characterizing the HIV epidemic among fishermen and designing specific intervention strategies suited to this highly migratory population.

In this prospective cohort study, the incidence rate of HIV infection among fishermen working on beaches around Lake Victoria in Kisumu County, Kenya was estimated. Additionally, factors associated with HIV prevalence and risk of HIV acquisition in this subpopulation, were explored. Potentially, these would rationalize and inform development of well-targeted interventions against new HIV infections among fishermen and the fishing communities at large.

\section{Methods}

\subsection{Study Design and Clinical Procedures}

Three hundred fishermen aged 18 - 47 years were recruited for evaluation of baseline HIV prevalence and prospective HIV acquisition over a period of one year. At enrolment, infection with Herpes simples virus type 2 (HSV-2) and human papillomavirus (HPV) were determined as potential baseline risk factors for HIV infection. Participants provided written informed consent prior to screening and enrollment. Structured interviews were conducted at baseline and repeated at study exit (month 12) to gather socio-demographic characteristics and risky sexual behavior. Genital examination for clinical STIs and collection of genital swabs (from the glans, head, shaft, scrotum and perineum) for HPV testing was performed at baseline and at every 3 months. Blood samples were collected for serological testing of HIV and HSV-2. All participants were offered free HIV counseling and testing, health education and condoms at each visit. Participants found to be HIV-positive were referred for free HIV care at patient support center nearest to their residence. The study was approved by Kenya Medical Research Institutes Scientific and Ethical Review Committees (SSC No. 2014).

\subsection{Laboratory Detection of HIV, HPV and HSV-2}

HIV serostatus was assessed by two rapid test kits in parallel: Determine (ABBOTT Laboratories, Diagnostic 
division, Chicago IL, USA) and UniGold HIV 1/2 rapid kit (Trinity Biotech, Ireland USA) with all concordant HIV positive or HIV discordant results confirmed by enzyme immunoassays: Vironostika ELISA (Bio Merieux Vironostika HIV Uni-Form II plus O Antigen/Antibody ELISA, Marcy l'Etoile, France) and Murex HIV 1/2 Combo (Murex Biotech Limited, Dartford, UK). Men with concordant negative results were evaluated for HIV incidence at the study exit. Baseline HPV infection was determined by polymerase chain reaction (PCR) using PGMY11/09 primer set and detection by genotype-specific probes multiples Luminex assay for 33 important genital HPV genotypes (HR: 16, 18, 26, 31, 33, 35, 39, 45, 51, 52, 53, 55, 56, 58, 59, 66, 68, 73, 82, 83 and LR: 6, 11, 40, 42, 54, 61, 62, 67, 70, 72, 81, 84, CP6108). Baseline HSV-2 infection was determined by HSV-2 enzyme-linked immunosorbent assay (ELISA) (Kalon Biological Ltd., Guilford, UK), as per manufacturer's instructions.

\subsection{Statistical Analysis}

HIV incidence and person-time calculations were performed with the assumption that HIV infection occurred at any time between baseline HIV negative serology test and study exit (after 12 months) positive serological test. HIV incidence was estimated per 100 person-years. For prevalence of HIV analyses, associations with fixed covariates such as age, marital status, and HPV/HSV-2 status at enrollment, as well as sexual risk behavior (number of partners, sexual relationships and condom use) reported at baseline and exit of the study were assessed by chi square, logistic regression and Fisher's exact for smaller numbers $(<6)$. Risk factors with a p-value less than 0.10 in bivariate logistic regression analysis were entered into a multivariate multiple logistic regression model to estimate adjusted measures of association for HIV prevalence (aOR) and incidence rate ratio (aIRR) at 95\% confidence intervals (95\% CIs) for HIV acquisition. SPSS version 18 (SPSS, Chicago, IL) and Stata version 12 (StataCorp LP 4905 Lakeway Drive College Station, Texas 77845 USA) were used.

\section{Results}

\subsection{Baseline Background Characteristics of Sampled Fishermen}

Of the 326 eligible fishermen, $300(92.0 \%)$ aged 18 - 47 years who provided written informed consent, were enrolled in the study and followed up for one year between September 2011 and December 2012. Of the 26 who did not consent to the study, 25 (96\%) declined due to blood draws and 1 (4\%) was not willing to be followed up. Of the 300 men, 70 were HIV positive at baseline. Table 1 shows background characteristics of fishermen enrolled in the study. The study population had a mean (SD) age of 27.7 (6.4). The mean (SD) age at sexual debut was 15 (3.7) years. The majority of men, 77\% (232/300) were married and 57\% had attained primary education. Among married men, 135 (57\%) had multiple partners with at least one new partnership formation in the year prior to the study compared to $53(83 \%)$ among single men who were 3.6 times as likely as married men to report multiple sexual partners in this period; OR $=3.60$ (95\% CI: 1.72 - 7.73). Additionally, single men were significantly younger with a mean (SD) age of 22.6 (3.39) compared to married men who had a mean age of 29.0 (6.34); $\mathrm{P}<0.001$. A significant number of men; 183 (61\%) $\mathrm{P}<0.01$ and 118 (39\%) $\mathrm{P}<0.05$ never used condoms with frequent sexual partners and new sexual partners respectively. Seventy seven men (25.8\%) reported a history of STI and the majority (81.3\%) reported having ever had an HIV test.

\subsection{Baseline HIV Infection}

Among the 300 fishermen, HIV prevalence was 23\% (95\% CI: 18.5 - 28.1). As shown in Table 2, the number of sexual partners in 6 months prior to study participation did not differ significantly by HIV status. Unlike among HIV positive men, the majority of HIV negative men were significantly of younger age (70\%), had multiple sexual partners in the year prior to study participation (65\%) and reported no history of STI (82\%); p-values as shown in Table 2. Conversely, proportions of baseline HSV-2 (76\% vs. 50\%) and HPV (69\% vs. 44\%) infection were significantly higher among HIV positive men compared to HIV negative men $(\mathrm{P}<0.001)$. HIV negative men were younger $(\mathrm{P}<0.001)$, had a higher number of sexual partners lifetime $(\mathrm{P}<0.001)$ and reported higher condom use with a new partner $(\mathrm{P}<0.001)$ compared to HIV positive men (Table 2).

In bivariate logistic regression (Table 3), history of STI, HPV and HSV-2 infection at enrolment were significantly associated with baseline HIV infection $(\mathrm{P}<0.001)$. HIV prevalence in the studied population increased with age. A unit increase in age was significantly associated with a one-fold increase in odds of being HIV in- 
Table 1. Baseline background characteristics of sampled fishermen.

\begin{tabular}{|c|c|c|}
\hline Characteristic $(\mathrm{N}=300)$ & Category & N (\%) \\
\hline \multirow{2}{*}{ Age } & Mean age (SD) & $27.7(6.4)$ \\
\hline & Median age (IQR) & $26.5(21-32)$ \\
\hline School years & Mean number of years (SD) & $8.8(3.1)$ \\
\hline \multirow{2}{*}{ Ethnicity } & Luo & $283(94.3 \%)$ \\
\hline & Other & $17(5.7 \%)$ \\
\hline \multirow{2}{*}{ Monthly income } & Income $\leq 115$ US\$ $(10,000 \mathrm{KShs})$ & $273(91.0 \%)$ \\
\hline & Income > 115 US\$ (10,000 KShs) & $27(9.0 \%)$ \\
\hline \multirow{4}{*}{ Religion } & Mainline Protestant & $75(25.0 \%)$ \\
\hline & Catholic & $46(15.3 \%)$ \\
\hline & Independent African churches & $131(43.7 \%)$ \\
\hline & Other & $48(16.0 \%)$ \\
\hline \multirow{3}{*}{ Duration of vocational training } & Less than 1 year & $22(32.4 \%)$ \\
\hline & 1 - 2 years & 33 (48.5\%) \\
\hline & More than 2 years & $13(19.1 \%)$ \\
\hline \multicolumn{3}{|l|}{ Sexual History: } \\
\hline \multirow{2}{*}{ Age of sexual debut } & Mean age (SD) & $13.5(3.7)$ \\
\hline & Median age (IQR) & $13(5)$ \\
\hline \multirow{2}{*}{ Condom use at sexual debut } & Yes & $20(6.7 \%)$ \\
\hline & No & $280(93.3 \%)$ \\
\hline \multirow[t]{2}{*}{ History of HIV test: } & Ever tested for HIV & $243(81.3 \%)$ \\
\hline & Baseline CD4 (HIV Positive) & 518.9 (297.31) cells/ $\mu \mathrm{l}$ \\
\hline \multirow{3}{*}{ Immunologic parameters, $\mathrm{N}$ = 287; (mean, SD): } & Baseline CD4 (HIV Negative) & 922.7 (304.32) cells/ $\mu \mathrm{l}$ \\
\hline & Baseline CD4 (overall) & 829.8 (346.82) cells/ $\mu \mathrm{l}$ \\
\hline & White blood cells $\left(\times 10^{9} / \mathrm{L}\right)$ & $5.6(1.53)$ \\
\hline
\end{tabular}

Table 2. Characteristics of fishermen by HIV status at study enrollment.

\begin{tabular}{|c|c|c|c|c|c|c|}
\hline \multirow{2}{*}{ Characteristic } & \multicolumn{2}{|c|}{ HIV Positive $(\mathrm{N}=70)$} & \multicolumn{2}{|c|}{ HIV Negative $(\mathrm{N}=230)$} & \multicolumn{2}{|c|}{ Total $(\mathrm{N}=300)$} \\
\hline & n (\%) & P-Value & n (\%) & P-Value & n (\%) & P-Value/(95\% CI) \\
\hline Age & & 0.396 & & $<0.001$ & & $<0.001$ \\
\hline 18 - 28 years & $33(47.1)$ & & $161(70)$ & & $194(64.7)$ & $(59.2-70.1)$ \\
\hline 29 - 47 years & 37 (52.9) & & $69(30)$ & & $106(35.3)$ & $(29.9-40.8)$ \\
\hline Marital status & & $<0.001$ & & $<0.001$ & & $<0.001$ \\
\hline single & $9(12.9)$ & & 55 (23.9) & & $64(21.3)$ & $(16.7-26.0)$ \\
\hline Ever married & $61(87.1)$ & & $175(76.1)$ & & $236(78.7)$ & $(74.0-83.3)$ \\
\hline Circumcised & & $<0.001$ & & $<0.001$ & & $<0.001$ \\
\hline Yes & $11(15.7)$ & & $61(26.5)$ & & $72(24.0)$ & $(19.1-28.9)$ \\
\hline No & $59(84.3)$ & & $169(73.5)$ & & $228(76.0)$ & $(71.1-80.7)$ \\
\hline Sexual partners in 6 months & & 0.090 & & 0.777 & & 0.777 \\
\hline$\leq 1$ partner & 39 (55.7) & & $113(49.1)$ & & $152(50.7)$ & $(45.0-56.4)$ \\
\hline
\end{tabular}




\section{Continued}

\begin{tabular}{|c|c|c|c|c|c|c|}
\hline$>1$ partners & $31(44.3)$ & & $117(50.9)$ & & $148(49.3)$ & $(43.6-55.0)$ \\
\hline Sexual partners in 12 months & & 0.090 & & $<0.001$ & & $<0.001$ \\
\hline$<2$ partner & $31(44.3)$ & & $81(35.2)$ & & $112(37.3)$ & $(31.8-42.8)$ \\
\hline$\geq 2$ partners & 39 (55.7) & & $149(64.8)$ & & $188(62.7)$ & $(57.2-68.2)$ \\
\hline Sexual partners in lifetime & & $<0.001$ & & $<0.001$ & & $<0.001$ \\
\hline$\leq 5$ partners & $10(14.3)$ & & 48 (20.9) & & $108(36.0)$ & $(30.5-41.5)$ \\
\hline$>5$ partners & $60(85.7)$ & & $182(79.1)$ & & $192(64.0)$ & $(58.5-69.5)$ \\
\hline Commercial sex & & $<0.001$ & & $<0.001$ & & $<0.001$ \\
\hline No & $1(1.4)$ & & $33(14.3)$ & & $34(11.3)$ & $(7.7-14.9)$ \\
\hline Yes & 69 (98.6) & & $197(85.7)$ & & $266(88.7)$ & $85.1-92.3)$ \\
\hline \multicolumn{7}{|l|}{ Most recent sexual partner } \\
\hline Regular Girlfriend/Wife & $43(61.4)$ & Reference & $128(71.7)$ & Reference & $167(69.3)$ & $(50.0-61.3)$ \\
\hline Casual partner/Sex worker & 27 (38.6) & $<0.001$ & $65(28.3)$ & $<0.001$ & $92(30.7)$ & $(25.4-35.9)$ \\
\hline Condom use on last sexual act & & $<0.001$ & & $<0.001$ & & $<0.001$ \\
\hline No & 69 (98.6) & & $189(82.2)$ & & $258(86.0)$ & $(82.1-90.0)$ \\
\hline Yes & $1(1.4)$ & & $41(17.8)$ & & $42(14.0)$ & $(10.1-18.0)$ \\
\hline \multicolumn{7}{|l|}{ Condom use with new partner } \\
\hline Rarely (<25\%) & $44(62.9)$ & Reference & $63(27.4)$ & Reference & $107(35.7)$ & Ref \\
\hline Some of the time (25\% - 75\%) & $17(24.3)$ & 0.011 & 48 (20.9) & 0.221 & $65(21.7)$ & 0.003 \\
\hline Most of the time ( $>75 \%)$ & 9 (12.9) & $<0.001$ & 119 (51.7) & $<0.001$ & $128(42.7)$ & 0.265 \\
\hline Ever use of Condom & & $<0.001$ & & $<0.001$ & & $<0.001$ \\
\hline Ever used condom & $48(68.6)$ & & $195(84.8)$ & & $243(81.0)$ & $(76.5-85.5)$ \\
\hline Never used condom & $22(31.4)$ & & 35 (15.2) & & $57(19.0)$ & \\
\hline History of STI & & 0.777 & & $<0.001$ & & $<0.001$ \\
\hline No & $34(48.6)$ & & $189(82.2)$ & & $223(74.3)$ & $(69.3-79.2)$ \\
\hline Yes & $36(51.4)$ & & $41(17.8)$ & & 77 (25.7) & $(20.8-30.7)$ \\
\hline Baseline HSV-2 & & $<0.001$ & & 1.000 & & 0.090 \\
\hline Negative & 17 (24.3) & & $114(49.6)$ & & $131(43.7)$ & $(38.0-49.3)$ \\
\hline Positive & $53(75.7)$ & & $116(50.4)$ & & $169(56.3)$ & $(50.7-62.0)$ \\
\hline Baseline HPV & & $<0.001$ & & 0.090 & & 1.000 \\
\hline Negative & 22 (31.4) & & $129(56.1)$ & & $151(50.3)$ & $(44.6-56.0)$ \\
\hline Positive & 48 (68.6) & & 101 (43.9) & & 149 (49.7) & $(44.0-55.4)$ \\
\hline
\end{tabular}

fected at baseline; OR = 1.08 (95\% CI: 1.04 - 1.13). Older men ( $>28$ years old) were 2.6 times more likely to test positive for HIV at baseline compared to younger men ( $\leq 28$ years old); OR = 2.62 (95\% CI: 1.46 - 4.69) as shown in Table 3. Men who reported ever being married were 2 times more likely to be HIV positive at baseline in bivariate analysis OR = 2.13 (95\% CI: 1.02 - 4.93). Men in this study reported very low condom use: $7 \%$ at sexual debut, $10 \%$ with new sexual partner (at a frequency $>75 \%$ of the time), $14 \%$ at most recent sexual act and $43 \%$ with new sexual partner (at frequency $>75 \%$ of the time). However, those who reported ever using a condom OR $=0.39$ (95\% CI: $0.20-0.76)$, condom use with a frequency greater than $75 \%$ of the time with a new sexual partner OR $=0.18$ (95\% CI: $0.06-0.51)$ or used condom on the most recent sexual act OR $=0.07(95 \%$ CI: $0.01-0.50$ ), were less likely to test HIV positive at baseline. Circumcision status and/or the number of sexual partners at enrolment were not associated with baseline HIV status (Table 3). Married men who reported 
Table 3. Bivariate logistic regression of factors associated with baseline HIV infection.

\begin{tabular}{|c|c|c|c|}
\hline Characteristic & OR & $95 \%$ CI & P-value \\
\hline Age: 18 - 28 years & & Reference & \\
\hline $29-47$ years & 2.62 & $1.46-4.69$ & 0.001 \\
\hline Marital status: Single & & Reference & \\
\hline Ever married & 2.13 & $1.02-4.93$ & 0.048 \\
\hline Circumcision: Yes & & Reference & \\
\hline No & 1.94 & $0.95-3.93$ & 0.067 \\
\hline Sexual partners in 6 months: $<2$ partner & & Reference & \\
\hline$\geq 2$ partners & 1.19 & $0.68-2.08$ & 0.523 \\
\hline Sexual partners in 12 months: $\leq 2$ partner & & Reference & \\
\hline$>2$ partners & 1.04 & $0.58-1.85$ & 0.897 \\
\hline Sexual partners in lifetime: $\leq 5$ partners & & Reference & \\
\hline$>5$ partners & 4.45 & $2.17-9.14$ & $<0.001$ \\
\hline Commercial sex: No & & Reference & \\
\hline Yes & 11.56 & $1.65-23.12$ & 0.017 \\
\hline Baseline HSV-2: Negative & & Reference & \\
\hline Positive & 3.06 & $1.67-5.61$ & $<0.001$ \\
\hline Baseline HPV: Negative & & Reference & \\
\hline Positive & 2.79 & $1.58-4.92$ & $<0.001$ \\
\hline \multicolumn{4}{|l|}{ Relation with recent partner } \\
\hline All men: Girlfriend & 1.00 & $0.59-1.72$ & 0.993 \\
\hline Casual partner/Sex worker & 2.23 & $0.36-13.59$ & 0.386 \\
\hline Wife & 0.32 & $0.11-0.92$ & 0.035 \\
\hline Single men: Girlfriend & & Reference & \\
\hline Casual partner/Sex worker & 0.80 & $0.15-4.50$ & 0.761 \\
\hline Married men: Wife & & Reference & \\
\hline Girlfriend & 3.52 & $1.08-12.69$ & 0.020 \\
\hline Casual partner/Sex worker & 4.44 & $1.30-16.59$ & 0.007 \\
\hline Ever use of Condom: Yes & 0.39 & $0.20-0.76$ & 0.002 \\
\hline No & 2.55 & $1.31-4.96$ & 0.002 \\
\hline \multicolumn{4}{|l|}{ Condom use on recent sexual act: } \\
\hline No & 14.97 & $2.15-29.82$ & 0.005 \\
\hline Yes & 0.07 & $0.01-0.50$ & 0.005 \\
\hline \multicolumn{4}{|l|}{ Condom use with new partner: } \\
\hline Most of the time ( $>75 \%)$ & 0.18 & $0.06-0.51$ & 0.001 \\
\hline Some of the time ( $>25 \%)$ & 1.71 & $0.66-4.43$ & 0.266 \\
\hline Rarely $(<25 \%)$ & 4.14 & $2.35-7.29$ & 0.001 \\
\hline Ever had STI: No & & Reference & \\
\hline Yes & 4.86 & $2.72-8.65$ & $<0.001$ \\
\hline
\end{tabular}

having their most recent sexual act with a girlfriend OR = 3.52 (95\% CI: 1.08 - 12.69) or sex worker/casual partner OR $=4.44$ (95\% CI: 1.30 - 16.59) were more likely to be HIV positive at baseline compared to those who reported having the most recent sexual act with their wife. In stratified analysis, men infected with both HPV and HSV-2 at baseline were 6 times at increased risk of being detected with HIV infection at baseline 
compared to men negative for both HPV and HSV-2infections at baseline; OR = 6.19 ( 2.55 - 15.03). Only 6.7\% (5/75) and 38.7\% (36/93) were detected with HIV at baseline among those negative for both HPV/HSV-2 and those positive for both HPV/HSV-2infections respectively.

In multivariate logistic regression, age was significantly associated with baseline HIV infection (aOR = 1.05; 95\% CI: 1.02 - 1.11), with older men being more likely to test positive for HIV at baseline compared to younger men; aOR $=2.13$ (95\% CI: 1.25 - 5.07) as shown in Table 4. However, marital status and circumcision were not associated with baseline HIV infections (P > 0.05). History of STI (aOR: 4.21; 95\% CI: 2.07 - 9.34) and baseline HPV infection (aOR: 2.13 (95\% CI: 1.05 - 4.77) were positively associated with HIV infection. Higher number (>5) of lifetime sexual partners (aOR: 5.76; 95\% CI: 1.41 - 13.57) and engaging in transactional sex (exchange of fish, money and other favors for sex) (aOR: 10.98; 95\% CI: 1.86 - 19.34) were more likely to have HIV infection at baseline. However, consistent condom use over $75 \%$ of the time with new sexual partner, ever using condom and condom use on the most recent sexual act was protective with regards to HIV infection ( $\mathrm{p}<$ 0.01 as shown in Table 4). Conversely men who reported consistent use of condom ( $>75 \%$ of the time) were 2.6 times more likely to test HIV positive at baseline compared to those who rarely or inconsistently used condom (less than $25 \%$ of the time) with a regular sexual partner (aOR $=2.60$; 95\% CI: 1.17 - 7.77).

\subsection{Incident HIV Infection}

Of the 300 fishermen enrolled, 230 men were HIV negative at baseline of which 191 (83\%) returned for the scheduled study exit follow-up visit after 12 months. This represented a crude total of 191 person-years (PY) of follow-up. During the 1 year period, 8 of the 191 (4.2\%) seroconverted, indicating an HIV incidence rate of 4.2 (95\% CI: 1.3 - 7.1) per 100 person-years. Men who seroconverted hada mean (SD) age of 22 (2.19) years, which was significantly lower compared to the mean (SD) age 27.0 (6.05) years of those men that remained negative at study exit, $(\mathrm{P}<0.001) \ldots$ Seven $(87.5 \%)$ of seroconverters were below 25 years.

As shown in Table 5, the majority of men with incident HIV infection were uncircumcised, single (never married), engaged in commercial sex, never used condom in their latest sexual act, reported multiples partners in

Table 4. Multivariate logistic regression of factors associated with baseline HIV infection.

\begin{tabular}{|c|c|c|c|}
\hline Characteristic & aOR & $95 \% \mathrm{CI}$ & P-value \\
\hline Age: 18 - 28 years & & Reference & \\
\hline 29 - 47 years & 2.13 & $1.25-5.07$ & 0.001 \\
\hline Marital status: Single & & Reference & \\
\hline Ever married & 1.57 & $0.15-2.17$ & 0.409 \\
\hline Circumcision: Yes & & Reference & \\
\hline No & 1.82 & $0.55-5.98$ & 0.325 \\
\hline Sexual partners in lifetime: $\leq 5$ partners & & Reference & \\
\hline$>5$ partners & 5.76 & $2.41-11.57$ & $<0.001$ \\
\hline Commercial sex: No & & Reference & \\
\hline Yes & 10.98 & $1.86-19.34$ & 0.021 \\
\hline Baseline HSV: Negative & & Reference & \\
\hline Positive & 1.54 & $0.67-3.57$ & 0.312 \\
\hline Baseline HPV: Negative & & Reference & \\
\hline Positive & 2.13 & $1.05-4.77$ & 0.047 \\
\hline Ever use of Condom: Ever used condom & & Reference & \\
\hline Never used condom & 2.67 & $1.19-5.99$ & 0.017 \\
\hline Condom use on recent sexual act: No & & Reference & \\
\hline Yes & 0.09 & $0.03-0.61$ & 0.009 \\
\hline \multicolumn{4}{|l|}{ Condom use with new partner: } \\
\hline Rarely $(<25 \%)$ & & Reference & \\
\hline Most of the time ( $>75 \%)$ & 0.21 & $0.08-0.55$ & 0.002 \\
\hline Ever had STI: No & & Reference & \\
\hline Yes & 4.21 & $2.07-9.34$ & $<0.001$ \\
\hline
\end{tabular}


Table 5. Factors associated with incident HIV infection among fishermen.

\begin{tabular}{|c|c|c|c|c|c|c|}
\hline Factors & $\mathrm{n}$ & $\begin{array}{c}\text { Incidence } \\
\text { (Rate \%) }\end{array}$ & IRR (95\% CI) & P-Value & $\operatorname{aIRR}(95 \% \mathrm{CI})$ & P-Value \\
\hline \multicolumn{7}{|l|}{ Age } \\
\hline 18 - 25 years & 88 & $7(8.0)$ & $8.19(1.03-65.32)$ & 0.025 & $5.57(0.89-34.64)$ & 0.066 \\
\hline $26-47$ years & 103 & $1(1.0)$ & Reference & & & \\
\hline \multicolumn{7}{|l|}{ Marital status } \\
\hline Single & 45 & $5(11.1)$ & $5.41(1.34-21.75)$ & 0.019 & $8.32(1.27$ - 54.67) & 0.027 \\
\hline Ever married & 146 & $3(2.1)$ & Reference & & & \\
\hline \multicolumn{7}{|l|}{ Circumcised } \\
\hline Yes & 51 & $1(2.0)$ & $0.39(0.05-3.11)$ & 0.092 & $0.99(0.09-10.68)$ & 0.991 \\
\hline No & 140 & $7(5.0)$ & Reference & & & \\
\hline \multicolumn{7}{|l|}{ Sexual partners in 6 months } \\
\hline$\leq 1$ partner & 94 & $4(4.3)$ & $0.95(0.24-3.68)$ & 1.00 & Not included & - \\
\hline$>1$ partners & 93 & $4(4.3)$ & Reference & & & \\
\hline \multicolumn{7}{|l|}{ Sexual partners in 12 months } \\
\hline$\leq 1$ partner & 70 & $1(1.4)$ & $0.25(0.03-1.97)$ & 0.102 & $0.87(0.07-10.92)$ & 0.913 \\
\hline$>$ 1partners & 121 & $7(5.8)$ & Reference & & & \\
\hline \multicolumn{7}{|l|}{ Sexual partners in lifetime } \\
\hline$\leq 5$ partners & 78 & $1(1.3)$ & $0.21(0.03-1.65)$ & 0.101 & $0.65(0.05-8.93)$ & 0.747 \\
\hline$>5$ partners & 113 & $7(6.2)$ & Reference & & & \\
\hline \multicolumn{7}{|l|}{ Commercial sex } \\
\hline No & 25 & $0(0.0)$ & $0.00(0.00-4.58)$ & 0.600 & Not included & - \\
\hline Yes & 166 & $8(4.8)$ & Reference & & & \\
\hline \multicolumn{7}{|l|}{ Most recent sexual partner } \\
\hline Wife/regular girlfriend & 139 & $1(0.7)$ & $0.05(0.00-0.39)$ & 0.001 & $0.03(0.01-0.35)$ & 0.004 \\
\hline Casual partner/Sex worker & 53 & $7(13.2)$ & Reference & & & \\
\hline \multicolumn{7}{|l|}{ Condom use on last sexual act } \\
\hline No & 162 & $7(4.3)$ & $1.25(0.16-9.81)$ & 1.000 & Not included & - \\
\hline Yes & 29 & $1(3.4)$ & Reference & & & \\
\hline \multicolumn{7}{|l|}{ Condom use with regular partner } \\
\hline$\geq 50 \%$ of the time & 14 & $0(0.0)$ & $0.00(0.00-9.17)$ & 1.000 & Not included & - \\
\hline$<50 \%$ of the time & 177 & $8(4.5)$ & Reference & & & \\
\hline \multicolumn{7}{|l|}{ Condom use with new partner } \\
\hline$\geq 50 \%$ of the time & 108 & $1(0.9)$ & $0.10(0.00-0.85)$ & 0.022 & $0.08(0.01-0.89)$ & 0.039 \\
\hline$<50 \%$ of the time & 83 & $7(8.4)$ & Reference & & & \\
\hline \multicolumn{7}{|l|}{ Ever use of Condom } \\
\hline Ever used condom & 164 & $8(4.9)$ & Reference & & & \\
\hline Never used condom & 27 & $0(0.0)$ & $0.00(0.00-4.17)$ & 0.603 & Not included & - \\
\hline \multicolumn{7}{|l|}{ History of STI } \\
\hline No & 157 & $5(3.2)$ & Reference & & & \\
\hline Yes & 33 & $3(9.1)$ & $3.04(0.54-15.74)$ & 0.104 & $2.10(0.28-15.84)$ & 0.470 \\
\hline \multicolumn{7}{|l|}{ Baseline HSV-2 } \\
\hline Negative & 94 & $5(5.3)$ & $0.57(0.10$ - 2.83) & 0.493 & Not included & - \\
\hline Positive & 97 & $3(3.1)$ & Reference & & & \\
\hline \multicolumn{7}{|l|}{ Baseline HPV } \\
\hline Negative & 106 & $3(2.8)$ & Reference & & & \\
\hline Positive & 85 & $5(5.9)$ & $2.15(0.43-11.73)$ & 0.470 & Not included & - \\
\hline
\end{tabular}


previous 12 months and $>5$ sexual partners lifetime at baseline. Six of 8 men (75\%) with incident HIV infection were HSV-2 positive at exit. However, only 3 (37.5\%) of these men had HSV-2 at baseline. Of the men with new HIV infection 63\% (5/8) had HPV infection at baseline. Moreover, 88\% (7/8) were detected with at least one new HPV genotype (different from those detected at baseline) in the course of study follow-up and $71 \%$ (5/7) of these men had multiple new HPV genotypes. All these men had a baseline CD4 $>700$ (mean = 852, SD $=162.5$; median $=809$, IQR $=744.8$ - 938.3) cells/ $\mu$ l of blood before getting HIV infection but by the time of exit their CD4 had significantly (P < 0.001) dropped to mean (SD) CD4 of 516 (277.5); median (IQR) 461 (391.5 - 658.3) cells/ $\mu$ l of blood. Five (62.5\%) already had their CD4 dropped to $<500$ cells/ $\mu$ l of blood.

Multivariate logistic regression (Table 5) strengthened the association between marital status and HIV incidence. Single men were independently at a greater risk for HIV acquisition compared to married men, aIRR = 8.32 (95\% CI: 1.27 - 54.67). Young age had a borderline association with HIV acquisition; aIRR = 5.57 (95\% CI: 0.89 - 34.64). Men who had most recent sexual act with their wife/regular girlfriend and those who used condom ( $\geq 50 \%$ of the time) with new sexual partners were protected from acquiring HIV compared to men whose most recent sexual act was with a sex worker/casual partner and those who consistently used condom ( $<50 \%$ of the time) with new sexual partners; aIRR $=0.03$ (95\% CI: $0.01-0.35)$ and aIRR $=0.11$ (95\% CI: 0.01 - 0.89) respectively.

\section{Discussion}

\subsection{HIV Prevalence}

This study presents data from a one-year longitudinal follow-up of fishermen on the Kenyan beaches of Lake Victoria. It is one of the very few studies that have evaluated risk factors for HIV acquisition among fishermen. With a baseline HIV prevalence of $23.3 \%$, fishermen remain a subpopulation that is highly burdened by HIV compared to the general population. This was 4 times the national HIV prevalence of 5.6\% [19]. Similar high HIV prevalence (20\% - 28\%) among fishermen, have been previously reported in Kenya and Uganda [16] [20]-[22]. In comparison to other high-risk groups such as MSM, the HIV prevalence in this study was twice that observed in bisexual MSM in Mombasa, Kenya [23]. However, the HIV prevalence in this study was lower than 43\% observed among exclusive MSM in Mombasa, Kenya [23] and 37\% among women with high-risk sexual behavior in Uganda [24]. The independent risk factors (older age, a higher number of lifetime sexual partners, commercial sex, HPV infection and history of STI) associated with HIV prevalence in this study, were also observed in previous studies [20] [21] [24].

\subsection{HIV Incidence Rate}

The HIV incidence rate of 4.2 per 100 person-years among fishermen in this study was similar to rates found in previous studies among male subpopulations considered at higher risk for HIV infection. Seeley et al. (2012) found an HIV incidence rate of 4.9 person-years among fishing communities (with 5.2 person-years among men) on the shores of Lake Victoria in Uganda [25]. New HIV infection rate of 3.9 per 100 person-years was observed among men reporting high-risk sexual behavior [26] and 5.8 per 100 person-years among bisexual MSM [27] in Costal Kenya. Similarly, HIV incidence of 6.1 per 100 person-years was found among exclusive MSM in Mombasa, Kenya [28], while 3.4 per 100 person-years [29] and 5.4 per 100 person-years [30] observed among MSM in China. Moreover, HIV acquisition rate of 5.8 per 100 person-years was shown among patients and commercial sex workers attending STI clinics in Pune, India [31] and 3.66 per 100 person-years observed among female sex workers in Kampala, Uganda [32].

HIV incidence in this study was higher compared to 2 per 100 person-years and 1.4 per 100 person-years observed among uncircumcised men drawn from the general population in Kisumu, Kenya [33] and Rakai, Uganda [34] respectively, 0.9 among heterosexual men in Mombasa, Kenya. Similar contrasting lower incidence rates were observed among high risk men in low HIV prevalence countries of: 1.24 per 100 person-years among MSM in Victoria, Australia [35] and 1.9 per 100 person-years among MSM in six US cities [36]. This suggests that the sexual behavior of fishermen in this study is comparable to that of men and women with high-risk sexual behavior living in high HIV prevalence communities.

\subsection{Risk Factors for Incidence}

Independent risk factors for HIV acquisition from this study were similar to those of previous studies assessing 
factors associated with incident HIV infection. Young age [25] [32], being single [27] [34], recent sexual intercourse with sex worker/casual partner [35] [37] and unprotected sex with new sexual partners [27] [32] [35] [36] were significantly associated with new HIV infection. Surprisingly, incident HIV infection was not associated with baseline HSV-2 infection in this study. This finding was largely unexpected given the high baseline HSV-2 (56.3\%) prevalence in this study of men with high risk sexual behavior, and the strong association between HIV and HSV-2 at baseline. However, similar results were documented by Supriya et al. (2012) in their Kisumu circumcision trial [33]. In contrast, other previous studies found baseline HSV-2 infection, a significant risk factor for HIV acquisition in men [34] [36] [38].

Although, evaluation of risk factors for HIV incidence had study power limitations which confined analysis to the eight seroconversion events that occurred in the study, the observed increased risk for new HIV acquisition among young single men was not surprising. In this study, single men were 3 times as likely as married men to report a new sexual partner(s) in the past 12 months. In the effort to provide explanation to why MSM are at increased risk for HIV compared to heterosexual men, Sara et al. (2012) found that 86\% of young MSM (18 - 24 years) compared to $56 \%$ of young heterosexual men (18 - 24 years) acquired a new sexual partner in the previous year [39]. This was similar to $83 \%$ observed in this study among younger single men compared to $57 \%$ among married men who formed a new sexual partnership in the same period of time. This similarity in addition to low condom use with new sexual partners may partially explain the higher risk for HIV incidence among young single fishermen.

STIs that induce the activation and recruitment of CD4+ T lymphocytes into clinical (subclinical) mucosal lesions associated with disrupted mucosal membrane likely increase HIV acquisition [40] [41]. Earlier studies observed that HIV seroconversion was associated with incident STI infections: syphilis [30] [35], HSV-2 [31] [33] [34] [42], Mycoplasma genitalium [32] and gonorrhea [27]. This suggests that these infections potentially increase susceptibility to HIV infection, but more importantly that they share a mode of transmission and thus are biological markers for exposure to unprotected sexual behavior. New, current, or history of STI is strong indicators of previous or current exposure to unsafe sexual practice; which is the primary major risk factor for HIV acquisition and transmission. Subramanian et al. (2013) documented a significant decline in STI prevalence and stable HIV prevalence in India. This was due to a large scale HIV prevention program targeting safer sexual practices among high-risk MSM in high-prevalence state of Tamil Nadu [43]. Two recent randomized clinical trials successfully demonstrated that antiretroviral drugs can be used for HIV prevention. The Partners Pre-exposure prophylaxis (PrEP) trial showed that tenofovir-emtricitabine (TDF-FTC) conferred $75 \%$ protection against HIV acquisition by HIV negative spouses among HIV discordant heterosexual couples [44]. Cohen et al. demonstrated a 96\% reduction in linked HIV transmission due to the effect of early antiretroviral therapy (ART) compared to delayed therapy administered to HIV positive spouses among heterosexual HIV discordant couples [45]. A global rollout of a multipronged program integrating PrEP, treatment for prevention (early ART) and safer sexual practices in groups with high-risk sexual behavior may reduce the incidence of HIV and other STIs.

\section{Conclusion}

Fishermen experience a high burden of HIV infection. Due to compounding and overlapping behavioral and sexual risk factors for STIs and HIV, the findings of this study suggest that high-risk unsafe sex could be the most important predisposing factor for HIV acquisition. The success in mitigating the HIV epidemic potentially lies in a renewed call for innovative revamping and strengthening of safer sex HIV preventions strategies fortified with the use of antiretroviral drugs. Well-targeted risk reduction interventions for high risk groups such as fishermen are urgently needed to prevent new HIV infections among most at risk subpopulations and the general population.

\section{Conflict of Interest}

The authors declare that there is no conflict of interests regarding the publication of this paper.

\section{Acknowledgements}

We acknowledge all the study participants and the Beach Management Units on the study beaches for their commitment and cooperation during this study. We feel indebted to all the research assistants who worked tire- 
lessly in the field successfully implementing this study. We sincerely appreciate the Director KEMRI and the Director Centre for Microbiology Research (CMR) KEMRI for their unwavering institutional support. This study was fully funded by the Consortium for National Health Research (CNHR) Kenya, Research Leadership Grant (RLG) 026/2009.

\section{References}

[1] UNAIDS and WHO (2009) AIDS Epidemic Update. December 2009. UNAIDS, Geneva.

[2] Coovadia, H.M. and Hadingham J. (2005) HIV/AIDS: Global Trends, Global Funds and Delivery Bottlenecks. Globalization and Health, 1, 13. http://dx.doi.org/10.1186/1744-8603-1-13

[3] Velayati, A.A., Bakayev, V., Bahadori, M., et al. (2007) Religious and Cultural Traits in HIV/AIDS Epidemics in Sub-Saharan Africa. Archives of Iranian Medicine, 10, 486-497.

[4] Agot, K.E., Vander Stoep, A., Tracy, M., Obare, B.A., Bukusi, E.A., et al. (2010) Widow Inheritance and HIV Prevalence in Bondo District, Kenya: Baseline Results from a Prospective Cohort Study. PLoS ONE, 5, e14028. http://dx.doi.org/10.1371/journal.pone.0014028

[5] Likatavicius, G., and van de Laar, M.J. (2011) HIV infection and AIDS in the European Union and European Economic Area, 2010. Eurosurveillance, 16, pii=20030. http://www.eurosurveillance.org/ViewArticle.aspx?ArticleId=20030

[6] Lingappa, J.R., Lambdin, B., Bukusi, E.A., Ngure, K., Kavuma, L., et al. (2008) Regional Differences in Prevalence of HIV-1 Discordance in Africa and Enrollment of HIV-1 Discordant Couples into an HIV-1 Prevention Trial. PLoS ONE 3, e1411. http://dx.doi.org/10.1371/journal.pone.0001411

[7] Dunkle, K.L., Stephenson, R., Karita, E., et al. (2008) New Heterosexually Transmitted HIV Infections in Married or Cohabiting Couples in Urban Zambia and Rwanda: An Analysis of Survey and Clinical Data. Lancet, 371, 2183-2191. http://dx.doi.org/10.1016/S0140-6736(08)60953-8

[8] Anand, A., Shiraishi, R.W., Bunnell, R.E., Jacobs, K., Solehdin, N., et al. (2009) Knowledge of HIV Status, Sexual Risk Behaviours and Contraceptive Need among People Living with HIV in Kenya and Malawi. AIDS, 23, 1565-1573. http://dx.doi.org/10.1097/QAD.0b013e32832cb10c

[9] Pandey, A., Benara, S.K., Roy, N., Sahu, D., Thomas, M., et al. (2008) Risk Behaviour, Sexually Transmitted Infections and HIV among Long-Distance Truck Drivers: A Cross-Sectional Survey along National Highways in India. AIDS, 22, S81-S90. http://dx.doi.org/10.1097/01.aids.0000343766.00573.15

[10] Stefan, B., Beyrer, C., Muessig, K., et al. (2012) Burden of HIV among Female Sex Workers in Low-Income and Middle-Income Countries: A Systematic Review and Meta-Analysis. The Lancet Infectious Diseases, 12, 538-549. http://dx.doi.org/10.1016/S1473-3099(12)70066-X

[11] Delany-Moretlwe, S., Bello, B., Kinross, P., et al. (2013) HIV Prevalence and Risk in Long-Distance Truck Drivers in South Africa: A National Cross-Sectional Survey. International Journal of STD \& AIDS, 25, 428-438.

[12] Allison, E.H. and Seeley, J.A. (2004) Another Group at High Risk for HIV. Science, 305, 1104. http://dx.doi.org/10.1126/science.305.5687.1104b

[13] Allison, E.H. and Seeley, J.A. (2004) HIV and AIDS among fisherfolk: A Threat to "Responsible Fisheries”? Fish \& Fisheries, 5, 215-234. http://dx.doi.org/10.1111/j.1467-2679.2004.00153.x

[14] Entz, A.T., Ruffolo, V.P., Chinveschakitvanich, V., Soskolne, V. and van Griensven, G.J. (2000) HIV-1 Prevalence, HIV-1 Subtypes and Risk Factors among Fishermen in the Gulf of Thailand and the Andaman Sea. AIDS, 14, 1027-1034. http://dx.doi.org/10.1097/00002030-200005260-00015

[15] Akumu, J., Odongkara, K., Masette, M., Khaidhiwa, M., et al. (2006) Prevalence and Impacts of HIV/AIDS and Other Diseases, Indigenous Knowledge and Nutritional Status of Fisher Communities of Lake Albert. NaFIRRI. National Agricultural Research Organisation.

[16] Kwena, Z.A., Bukusi, E.A., Ng’ayo, M.O., Buffardi, A.L., Nguti, R., Richardson, B., Sang, N.M. and Holmes, K. (2010) Prevalence and Risk Factors for Sexually Transmitted Infections in a High-Risk Occupational Group: The Case of Fishermen along Lake Victoria in Kisumu, Kenya. International Journal of STD \& AIDS, 21, 708-713. http://dx.doi.org/10.1258/ijsa.2010.010160

[17] Odongkara, K., Akumu, J.K., Masette, M., Khisa, G., et al. (2006) Prevalence of HIV/AIDS among Fisher Communities and Its Impact on Fisheries Management. NaFIRRI, Jinja.

[18] Seeley, J.A. and Allison, E.H. (2005) HIV/AIDS in Fishing Communities: Challenges to Delivering Antiretroviral Therapy to Vulnerable Groups. AIDS Care, 17, 688-697. http://dx.doi.org/10.1080/09540120412331336698

[19] Kenya AIDS Indicator Survey (KAIS) 2012.

[20] Opio, A., Muyonga, M. and Mulumba, N. (2013) HIV Infection in Fishing Communities of Lake Victoria Basin of 
Uganda—A Cross-Sectional Sero-Behavioral Survey. PLoS ONE, 8, Article ID: e70770. http://dx.doi.org/10.1371/journal.pone.0070770

[21] Asiki, G., Mpendo, J., Abaasa, A., Agaba, C., Nanvubya, A., Nielsen, L., Seeley, J., Kaleebu, P., Grosskurth, H. and Kamali, A. (2011) HIV and Syphilis Prevalence and Associated Risk Factors among Fishing Communities of Lake Victoria, Uganda. Sexually Transmitted Infections, 87, 511-515. http://dx.doi.org/10.1136/sti.2010.046805

[22] Kiwanuka, N., Ssetaala, A., Mpendo, J., Wambuzi, M., et al. (2013) High HIV-1 Prevalence, Risk Behaviours, and Willingness to Participate in HIV Vaccine Trials in Fishing Communities on Lake Victoria, Uganda. Journal of the International AIDS Society, 16, 18621. http://dx.doi.org/10.7448/IAS.16.1.18621

[23] Sanders, E.J., Grahamc, S.M., Okuku, H.S., van der Elst, E.M., Muhaari, A., Davies, A., Peshu, N., Price, M., McClelland, R.S. and Smith, A.D. (2007) HIV-1 Infection in High Risk Men Who Have Sex with Men in Mombasa, Kenya. AIDS, 21, 2513-2520. http://dx.doi.org/10.1097/QAD.0b013e3282f2704a

[24] Vandepitte, J., Bukenya, J., Weiss, H.A., Nakubulwa, S., Francis, S.C., Hughes, P., Hayes, R. and Grosskurth, H. (2011) HIV and Other Sexually Transmitted Infections in a Cohort of Women Involved in High Risk Sexual Behaviour in Kampala, Uganda. Sexually Transmitted Diseases, 38, 316-323.

[25] Seeley, J., Nakiyingi-Miiro, J., Kamali, A., Mpendo, J., Asiki, G., Abaasa, A., De Bont, J., Nielsen, L. and Kaleebu, P. (2012) High HIV Incidence and Socio-Behavioral Risk Patterns in Fishing Communities on the Shores of Lake Victoria, Uganda. Sexually Transmitted Diseases, 39, 433-439. http://dx.doi.org/10.1097/OLQ.0b013e318251555d

[26] Okuku, H.S., Sanders, E.J., Nyiro, J., Ngetsa, C., Ohuma, E., McClelland, R.S., Price, M.A. and Graham, S.M. (2011) Factors Associated with Herpes Simplex Virus Type 2 Incidence in a Cohort of HIV-1-Seronegative Kenyan Men and Women Reporting High-Risk Sexual Behavior. Sexually Transmitted Diseases, 38, 837-844. http://dx.doi.org/10.1097/OLQ.0b013e31821a6225

[27] Sanders, E.J., Okuku, H.S., Smith, A.D., Mwangome, M., Wahome, E., Fegan, G., Peshu, N., van der Elst, E.M., Price, M.A., McClelland, R.S. and Graham, S.M. (2013) High HIV-1 Incidence, Correlates of HIV-1 Acquisition, and High Viral Loads Following Seroconversion among Men Who Have Sex with Men in Coastal Kenya. AIDS, 27, 437-446. http://dx.doi.org/10.1097/QAD.0b013e32835b0f81

[28] Price, M.A., Wasima, R., Mwangome, M., Mutua, G., Middelkoop, K., Roux, S., Okuku, H.S., Bekker, L.G., Anzala, O., Ngugi, E., Stevens, G., Chetty, P., Amornkul, P.N. and Sanders, E.J. (2012) Identifying At-Risk Populations in Kenya and South Africa: HIV Incidence in Cohorts of Men Who Report Sex With Men, Sex Workers, and Youth. JAIDS Journal of Acquired Immune Deficiency Syndromes, 59, 185-193. http://dx.doi.org/10.1097/QAI.0b013e31823d8693

[29] Li, S.M., Zhou, Z.H., Jiang, S.L., Liu, Y.J., Li, D.L., Zhang, Z., Zhang, X.X., Luo, F.J., Ruan, Y.H. and Shao, Y.M. (2011) Incidence and Risk Factors of HIV and Syphilis Seroconversion among Men Who Have Sex with Men in Beijing. Chinese Journal of Preventive Medicine, 45, 118-122.

[30] Xu, J.J., Zhang, M., Brown, K., Reilly, K., Wang, H.L., Hu, Q.H., Ding, H.B., Chu, Z.X., Bice, T. and Shang, H. (2010) Syphilis and HIV Seroconversion among a 12-Month Prospective Cohort of Men Who Have Sex with Men in Shenyang, China. Sexually Transmitted Diseases, 37, 432-439. http://dx.doi.org/10.1097/OLQ.0b013e3181d13eed

[31] Reynolds, S.J., Risbud, A.R., Shepherd, M.E., Zenilman, J.M., Brookmeyer, R.S., Paranjape, R.S., Divekar, A.D., Gangakhedkar, R.R., Ghate, M.V., Bollinger, R.C. and Mehendale, S.M. (2003) Recent Herpes Simplex Virus Type 2 Infection and the Risk of Human Immunodeficiency Virus Type 1 Acquisition in India. Journal of Infectious Diseases, 187, 1513-1521. http://dx.doi.org/10.1086/368357

[32] Vandepitte, J., Weiss, H.A., Bukenya, J., Nakubulwa, S., Mayanja, Y., Matovu, G., Kyakuwa, N., Hughes, P., Hayes, R. and Grosskurth, H. (2013) Alcohol Use, Mycoplasma genitaliumand Other STIs Associated with HIV Incidence among Women at High Risk in Kampala, Uganda. JAIDS Journal of Acquired Immune Deficiency Syndromes, 62, 119126. http://dx.doi.org/10.1097/QAI.0b013e3182777167

[33] Mehta, S.D., Moses, S., Parker, C.B., Agot, K., Maclean, I. and Bailey, R.C. (2012) Circumcision Status and Incident Herpes Simplex Virus Type 2 Infection, Genital Ulcer Disease, and HIV Infection. AIDS, 26, 1141-1149. http://dx.doi.org/10.1097/QAD.0b013e328352d116

[34] Aaron, A.R.T., Victor, S., Godfrey, K., Amy, E.O., et al. (2009) Incident HIV and Herpes Simplex Virus Type 2 Infection among Men in Rakai, Uganda. AIDS, 23, 1589-1594. http://dx.doi.org/10.1097/QAD.0b013e32832d4042

[35] Guy, R.J., Spelman, T., Stoove, M., El-Hayek, C., Goller, J., Fairley, C.K., Leslie, D., Tee, B.K., Roth, N., Grulich, A.E. and Hellard, M.E. (2011) Risk factors for HIV Seroconversion in Men Who Have Sex with Men in Victoria, Australia: Results from a Sentinel Surveillance System. Sexual Health, 8, 319-329. http://dx.doi.org/10.1071/SH10095

[36] Brown, E.L., Wald, A., Hughes, J.P., Morrow, R.A., Krantz, E., Mayer, K., Buchbinder, S., Koblin, B. and Celum, C. (2006) High Risk of Human Immunodeficiency Virus in Men Who Have Sex with Men with Herpes Simplex Virus Type 2 in the EXPLORE Study. American Journal of Epidemiology, 164, 733-741. http://dx.doi.org/10.1093/aje/kwj270 
[37] Sutcliffe, C.G., Aramrattana, A., Sherman, S.G., Sirirojn, B., German, D., Wongworapat, K., Quan, V.M., Keawvichit, R. and Celentano, D.D. (2009) Incidence of HIV and Sexually Transmitted Infections and Risk Factors for Acquisition among Young Methamphetamine Users in Northern Thailand. Sexually Transmitted Diseases, 36, 284-289. http://dx.doi.org/10.1097/OLQ.0b013e318191ba17

[38] Sobngwi-Tambekou, J., Taljaard, D., Lissouba, P., Zarca, K., Puren, A., Lagarde, E. and Auvert, B. (2009) Effect of HSV-2 Serostatus on Acquisition of HIV by Young Men: Results of a Longitudinal Study in Orange Farm, South Africa. Journal of Infectious Diseases, 199, 958-964. http://dx.doi.org/10.1086/597208

[39] Glick, S.N., Morris, M., Foxman, B., Aral, S.O., Manhart, L.E., Holmes, K.K. and Golden, M.R. (2012) A Comparison of Sexual Behavior Patterns among Men Who Have Sex with Men and Heterosexual Men and Women. JAIDS Journal of Acquired Immune Deficiency Syndromes, 60, 83-90. http://dx.doi.org/10.1097/QAI.0b013e318247925e

[40] Gupta, R., Warren, T. and Wald, A. (2007) Genital Herpes. Lancet, 370, 2127-2137. http://dx.doi.org/10.1016/S0140-6736(07)61908-4

[41] Rebbapragada, A., Wachihi, C., Pettengell, C., Sunderji, S., Huibner, S., Jaoko, W., Ball, B., Fowke, K., Mazzulli, T., Plummer, F.A. and Kaul, R. (2007) Negative Mucosal Synergy between Herpes Simplex Type 2 and HIV in the Female Genital Tract. AIDS, 21, 589-598. http://dx.doi.org/10.1097/QAD.0b013e328012b896

[42] Brown, J.M., Wald, A., Hubbard, A., et al. (2007) Incident and Prevalent Herpes Simplex Virus Type 2 Infection Increases Risk of HIV Acquisition among Women in Uganda and Zimbabwe. AIDS, 21, 1515-1523. http://dx.doi.org/10.1097/QAD.0b013e3282004929

[43] Subramanian, T., Ramakrishnan, L., Aridoss, S., Goswami, P., Kanguswami, B., Shajan, M., Adhikary, R., Purushothaman, G.K.C., Ramamoorthy, S.K., Chinnaswamy, E., Veeramani, I.B. and Paranjape, R.S. (2013) Increasing Condom Use and Declining STI Prevalence in High-Risk MSM and TGs: Evaluation of a Large-Scale Prevention Program in Tamil Nadu, India. BMC Public Health, 13, 857.

[44] Baeten, J.M., Donnell, D., Ndase, P., Mugo, N.R., et al. (2012) Antiretroviral Prophylaxis for HIV Prevention in Heterosexual Men and Women. New England Journal of Medicine, 367, 399-410. http://dx.doi.org/10.1056/NEJMoa1108524

[45] Cohen, M.S., Chen, Y.Q., McCauley, M., Gamble, T., et al. (2011) Prevention of HIV-1 Infection with Early Antiretroviral Therapy. New England Journal of Medicine, 365, 493-505. http://dx.doi.org/10.1056/NEJMoa1105243 
Scientific Research Publishing (SCIRP) is one of the largest Open Access journal publishers. It is currently publishing more than 200 open access, online, peer-reviewed journals covering a wide range of academic disciplines. SCIRP serves the worldwide academic communities and contributes to the progress and application of science with its publication.

Other selected journals from SCIRP are listed as below. Submit your manuscript to us via either submit@scirp.org or Online Submission Portal.
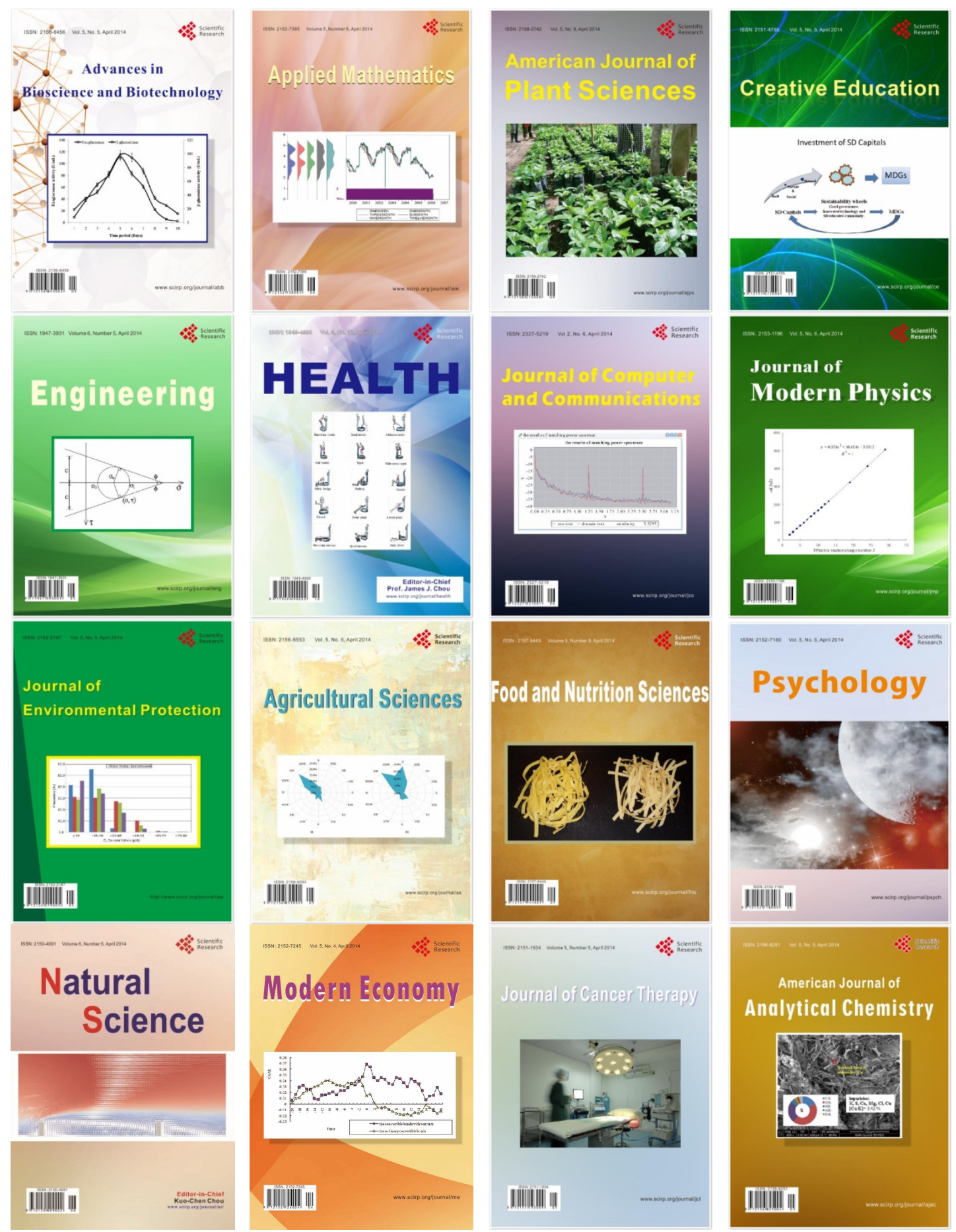